randomised controlled studies in psoriasis, "insulin dependent diabetes mellitus, ${ }^{12}$ and uveitis ${ }^{13}$; and promising results have been obtained in rheumatoid arthritis, ${ }^{14}$ myasthenia gravis, ${ }^{15}$ primary biliary cirrhosis,${ }^{16}$ and Crohn's disease. ${ }^{17}$ Its efficacy has also been shown in uncontrolled trials in the nephrotic syndrome, systemic lupus erythematosus, and various dermatological and haematological disorders, although not in multiple sclerosis. ${ }^{18}$ In psoriasis in particular, cyclosporin has been shown to be effective and safe for up to one year provided that the guidelines for treatment are strictly observed. ${ }^{19}$ Long term experience in these conditions is still limited.

Several features are common to these studies in different conditions. Cyclosporin has a quick onset of effect (within two to 12 weeks, depending on dosage), but relapse after withdrawing it is almost universal and is in keeping with the reversible inhibitory action of cyclosporin on cytokine synthesis by $\mathrm{T}$ lymphocytes. Cyclosporin does not affect the clinical course of the disease. Nevertheless, many patients who are unresponsive to or intolerant of conventional drug treatment may benefit from cyclosporin or achieve a useful reduction in their steroid dosage.

Cyclosporin may do far more than simply act on $\mathrm{T}$ cells. It seems to be effective in some autoimmune disorders associated with antibodies - for example, pemphigus and pemphigoid and myasthenia gravis. In skin diseases it may well have an anti-inflammatory action through inhibiting eicosanoid synthesis, while in the nephrotic syndrome it may act predominantly through a haemodynamic action to reduce excretion of protein. Because of the possible drug interactions and other adverse effects careful review of all patients is mandatory. Among the guidelines for its safe use are an initial dosage of no more than $5 \mathrm{mg} / \mathrm{kg}$ a day, unless a rapid effect is critical, and the maintenance of trough blood concentrations of cyclosporin at $200 \mathrm{ng} / \mathrm{ml}$ or less (as measured by radioimmunoassay). If serum creatinine concentrations rise more than $30 \%$ above baseline the dose should be reduced. The use of cyclosporin in less advanced disease - for example, in acute type 1 diabetes - has to be individually and carefully balanced against the risks of both the disease and alternative treatment. Drug toxicity may outweigh the apparent benefit of improved efficacy. Long term follow up is essential to monitor blood pressure and to ascertain the risk of chronic irreversible renal impairment and the consequences of chronic immunosuppression.

Though further clinical trials of cyclosporin, both alone and in combination, are justified in autoimmune disease, these must be restricted to formal investigations conducted by experienced clinicians skilled in using cyclosporin and with facilities for monitoring the long term risks. Only then will it be possible to pass valid judgment on its value for autoimmune disease.

Reader in Immunology,

A W THOMSON

Immunopathology Laboratory,

Department of Pathology,

University of Aberdeen,

Aberdeen AB9 2ZD

Professor of Nephrology

Department of Nephrology and Institute of Urology,

University College and Middlesex School of Medicine,

London WC2A 2EX

1 Thiru S. Pathological effects of cyclosporin A in clinical practice. In: Thomson AW, ed. Cyclospurin. Mode of action and clinical applications. London: Kluwer Academic, 1989:303-64. Cyclosporin. Mode of action and clinical applications. London: Kluwer Academic,
Schindler R, ed. Ciclosporin in autoimmune disease. Berlin: Springer-Verlag, 1986.

2 Schindler R, ed. Ciclosporin in autommune disease. Berlin: Springer-Verlag, 1986.
3 Thomson AW, ed. Cyclosporin. Mode of action and clinical applications. London: Kluwer Academic, Thomson 1989.

4 Ryffel B. Pharmacology of cyclosporine. 6. Cellular activation: regulation of intracellular events by cyclosporine. Pharmacol Rev 1989;41:407-22.

5 Borel JF. Pharmacology of cyclosporin (Sandimmune). 4. Pharmacological properties in vivo. Pharmacol Rev 1989;41:259-371.
6 Granelli-Piperno A. Lymphokine gene expression in vivo is inhibited by cyclosporin A. $7 \mathrm{Exp}$ Med 1990;171:533-44

Crabtree GR. Contingent genetic regulatory events in T lymphocyte activation. Science 1989;243 355-60.

8 Gallagher RB, Cambier JC. Signal transmission pathways and lymphocyte function. Immunology Today 1990;11:187-9.

Thomson AW. FK-506. Profile of an important new immunosuppressant. Transplantation Reviews 1990;4:1-13.

10 Starzl TE, Todo S, Fung J, Demetris AJ, Venkataramman R, Jain A. FK-506 for liver, kidney and pancreas transplantation. Lancet $1989 ;$ ii: 1000 .

1 Mihatsch MJ, Wolff K, eds. Risk-benefit ratio of cyclosporin A (Sandimmun $\left.{ }^{\mathbf{R}}\right)$ in psoriasis. $B r \mathcal{Y}$ Derniatol 1990;122(suppl 36):1-115.

12 Canadian-European Randomized Control Trial Group. Cyclosporin-induced remission of IDDM after early intervention. Association of 1 year of cyclosporin treatment with enhanced insulin
secretion. Diabetes 1988:37:1574-82.

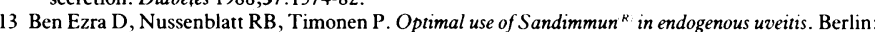
Springer, 1988

14 Tugwell $\mathrm{P}$, Bombardier $\mathrm{C}$, Gent $M$, et al. Low dose cyclosporin in patients with rheumatoid arthritis. Lancet 1990;335:1051-4.

15 Tindall RSA, Rollins JA, Phillips JT, Greenlee RG, Wells L, Belendiuk G. Preliminary results of a double-blind randomized, placebo-controlled trial of cyclosporin in myasthenia gravis. $N$ Eng f Med 1987;316:719-2

16 Wiesner TH, Ludwig J, Dindor ED, et al. A controlled trial of cyclosporin in the treatment of primary biliary cirrhosis. N Engl f Med 1990;322:1419-24.

17 Brynskov J, Freund L, Rasmussen SN, et al. A placebo-controlled, double-blind, randomized tria of cyclosporin therapy in active chronic Crohn's disease. N Engl F Med 1989;321:845-50.

18 Van Graffenried B, Friend D, Shand N, Schiess W, Timonen P. Cyclosporin A (Sandimmun ${ }^{\mathrm{R}}$ ) in autoimmune disorders. Thomson AW, ed. Cyclosporin. Mode of action and clinical applications. London: Kluwer Academic, 1989:213-50.

19 Anonymous. A consensus report: cyclosporin A therapy for psoriasis. Br f Dermatol 1990;122 (suppl 36): $1-3$.

\section{Child health computing}

\section{A springboard for a community health register}

One of the unsung successes of British child health services has been the development of computerised health information systems, pioneered in West Sussex in the early 1960s. ${ }^{.}$By exploiting surplus capacity on the county council's computer, West Sussex's public health department computerised its birth notifications and thus formed the basis for recording immunisation data. The system was developed so that it would organise appointments, produce invitations with appointment times, record the immunisation details, and then write a cheque for the doctor who did the immunisations. Soon West Sussex found that its immunisation rate had risen to at least $15 \%$ above that of neighbouring districts using manual recording methods. ${ }^{2}$ Other districts adopted similar systems and found not only that their immunisation performance improved but that morbidity - as measured by measles notifications - was reduced. ${ }^{3}$ Subsequently, the development of a national child health computer system was taken on by the NHS, along with the child health services themselves, and has now reached the point at which the system could form the basis of a total community register, forging links with primary care and recording events into adulthood.

When the NHS took over child health services in 1974 its computerised vaccination and immunisation system was based on the ICL mainframe computers operated by regional computer centres. The first two modules of the system - child register and immunisation - were generally available by 1977 and operational in $60 \%$ of districts in England and Wales by $1983 .{ }^{4} \mathrm{~A}$ system for scheduling preschool surveillance checks was implemented in 1984, followed by an extension to school health checks in $1985 . .^{5}$ In 1984 an alternative version of the system, written in MUMPS (Massachusetts University Medical Programme Systems) language and based on DEC equipment, provided an opportunity to move away from centralised batch processing to an on line system based in districts, and the ICL system soon followed suit in allowing direct data entry. Although the ICL and MUMPS systems have developed at different rates, both versions have a common core specification. Meanwhile some regions have 
gone it alone and developed their own systems, notably North East Thames.

All these systems are only as good as those using them, and training and updating staff in computer technology are major processes. But just as important is keeping users in touch with the providers. The MUMPS and ICL based systems receive advice, suggestions, and complaints from the Child Health Computing Committee, a national committee representing users-community paediatricians, general practitioners, clinical medical officers, health visitors, and health service administrators - and the centres of responsibility in Bristol and Cardiff. Each NHS region also has its own regional child health computing committee for promoting child health computing, tackling problems, introducing amendments, and seeking refinements.

Future possibilities might include recording neonatal biochemical screening, a growth monitoring programme, and computerised parent held records. Work is already in progress to link the system to community nursing systems such as COMCARE and COMWAY, which log health visitors' visits and other community work. There is a strong case for extending the child health system to provide a total community register, recording health care events in adults (such as cervical screening) as well as children, thereby exploiting existing technology and staff rather than building new systems.

In the short term there is an urgent need to link the system with those of the newly created family health services authorities, and pilot work is already under way. Those in primary care need to grasp the opportunity the system presents to increase immunisation and child health surveillance uptake while at the same time saving the administrative expenses of issuing appointments and reminders. The new spirit of collaboration between family health services authori- ties and child health was the theme of the conference "Partnerships in Practice" held in London in December, at which Professor Sir Michael Drury, professor of general practice in Birmingham, emphasised the importance of linking primary care and child health systems. Baroness Hooper, parliamentary undersecretary for health, also acknowledged the contribution already made by the child health system to the implementation of government policies on immunisation and developmental screening.

The strength of the child health system, now used by 138 of the 199 districts in England and Wales and all four health boards in Northern Ireland, lies in its ability to coordinate immunisation and developmental assessment services across the country within the framework of nationally agreed policies. ${ }^{67}$ Other countries are looking with interest at the system, which might eventually form the basis for a panEuropean health record.

Chairman, Child Health Computing Committee,

EUAN ROSS

Department of Community Paediatrics,

King's College School of Medicine,

London SE5 7RN

Chairman, Child Health System Management Executive,

NORMAN BEGG

PHLS Communicable Disease Surveillance Centre

London NW9 5EQ

1 Galloway TMCL. Management of vaccination and immunisation procedures by electronic computer. The Medical Officer 1963;109:232-3.

2 Galloway TMcL. Vaccination and immunisation by electronic data processing. The Medical Officer 1966;116:58-60.

3 Bussey AL, Harris AS. Computers and the effectiveness of the measles vaccination programme in England and Wales. Community Med 1979;1:29-35.

4 Walker CHM. Computing in child health: significant progress. BMF 1983;287:1400-1.

5 Rigby M. Child health comes of age. British fournal of Health Care Computing 1985;2:13-5.

6 Department of Health. Immunisation against infectious disease. London: HMSO, 1990.

7 Hall DMB, ed. Health for all children. A programme for child health surveillance. Oxford: Oxford University Press, 1989.

\section{Farewell Scrutator}

\section{Welcome back Hart}

Gordon Macpherson, it can now be revealed, is Scrutator. "The Week" he wrote before Christmas was his last, and now he has begun his retirement.

After five years in general practice on the south coast Gordon was with the BMA for six years before he crossed the courtyard to the journal in 1970 . He started with the association by having to tour the country explaining and selling the general practice charter (one of the most important medicopolitical events this century), often to large crowds of angry doctors. It took general practice from the wastelands to the centre of British medicine, where it has since remainedexplaining why the NHS is unsurpassed in its cost effectiveness. Gordon was also particularly concerned with setting up and running the association's planning unit, led by Henry. Miller, which produced several reports independent of the BMA. As he trod the corridors of the association he developed an unequalled feel for its moods and complexities.

His understanding of medical politics made Gordon invaluable to the $B M \mathcal{F}$. As well as editing the medicopolitical sections of the journal, and writing on politics in a warm, and highly readable style, Gordon has kept relations between the association and the journal close and productive. He is one of the best liked people in BMA House, and over the years many members of the association have sought his advice.
Gordon has deep misgivings about the changes currently occurring in the health service but has always kept his mind open to innovation, recognising the inevitability of some change.

Because Gordon brought such a particular style to the name of Scrutator we have decided that the name should leave with him. We will continue to carry The Week, but the signature will now be Hart - in honour of the journal's great editor of the nineteenth century, Ernest Hart, who brought about a plethora of reforms in Victorian society. In addition, our news section is to be renamed News and Political Review to reflect the prominence that political issues now have in international medicine; it will continue to carry news from around the world on medical and scientific developments. BMA Affairs will be renamed Medicopolitical Digest to acknowledge the breadth of medicopolitics and will continue in concentrated form to carry important matters of record. Thus the story of the agreement on juniors' hours of work is reported at the front of News and Political Review, the issue is analysed by Hart in The Week, and the wording of the agreement is given in Medicopolitical Digest.

RICHARD SMITH 